\title{
Research \& Development on the WPVC Electric Power Generation for Household Miniature Modular Facility
}

\author{
Zhongnian $\mathrm{LI}^{1, a}$ Qing WANG ${ }^{2, b}$ Tianying $\mathrm{LI}^{3, \mathrm{c}}$ \\ ${ }_{1,2,3}$ School of electrical \& energy engineering, Nantong Institute of Technology, Nantong, China \\ alznlzn2011@qq.com, b413887703@qq.com, c402915825@qq.com
}

\begin{abstract}
Keywords: household miniature modular WPVC electric power generation facility, energy storage facility, variable flow
\end{abstract}

Abstract. This WPVC (Wind PhotoVoltaic Complementary) electric power generation for household miniature modular facility, will essentially the WPVC miniature electric power generation facility /energy storage facility /converter facility/ control facility etc and load facility, that combination formation a number of modular micro power supply facility are designed to supply power to each household electrical device separately. In this paper, research \& development theory and technology which for micro wind turbines in the household miniature modular the WPVC electric power generation facility/ micro solar photovoltaic cell module panel facility/ micro controller facility/ micro converter facility/micro energy storage etc facility (research focuses on single-phase converter facilities, because as everyone knows household electric power source is usually a single-phase voltage source) are describes. In this paper, and also discusses the "household miniature modular WPVC electric power generation facilities "principle/research methods/selection essentials and green environmental protection, high performance price ratio, little and dainty, ready to use ,easy movement, installation \& maintenance simple and convenient characteristics. In addition, outline drawing of some devices for " the household miniature modular WPVC electric power generation facility " is given in this paper.

\section{Introduction}

Now the interconnected power supply network is a large power grid which integrates diversified power generation, long-distance transmission, power supply according to technical requirements, and power distribution according to the user's needs. The main problems are: the change of interconnected power network can track the load. With the increase of load peak valley difference, the load rate of interconnected power supply network will decline year by year, and the utilization ratio of power generation and transmission facilities will decline. The interconnection of power network, local accident easily spread, resulting in a large area of power supply network interconnection; and more huge accidents the probability of occurrence is higher (in recent years the worldwide blackout accidents have occurred, has fully exposed the vulnerability of power grid interconnection).

With the development of modern science and technology, the facilities of thousands on thousands of family life cannot do without electricity, electricity supply in some areas is not very stable, it is particularly important to the WPVC (Wind PhotoVoltaic Complementary) electric power generation device, the existing wind and solar power generation device volume is large and heavy, and is generally fixed the mobile device is difficult, inconvenient maintenance, therefore, a domestic miniature modular structure, little and dainty, mobile simple and convenient maintenance, green environmental protection, high cost of wind and solar power generation facilities need to be researched \& developed.

At the same time also obviously "domestic miniature modular wind and solar power generation facilities" green, little and dainty and easy moving, plug and play, easy installation and maintenance; and the energy (i.e. wind and solar) inexhaustible, inexhaustible, will become an important direction of development of electric energy facilities. 


\section{Basic Architecture for Household Miniature Modular WPVC Electric Power Generation Facility}

Researched \& developmented the household miniature modular WPVC electric power generation facility basic structure as shown in figure 1 in this paper,, which is mainly composed of micro wind turbine (No.1), micro (solar)photovoltaic panels (No.2) (No.3), micro controller, micro left converter ((No.4), micro right converter (No.5), micro batteries (No.6) and other devices to modular forms. The right and left micro converters mainly include inverters and rectifiers.

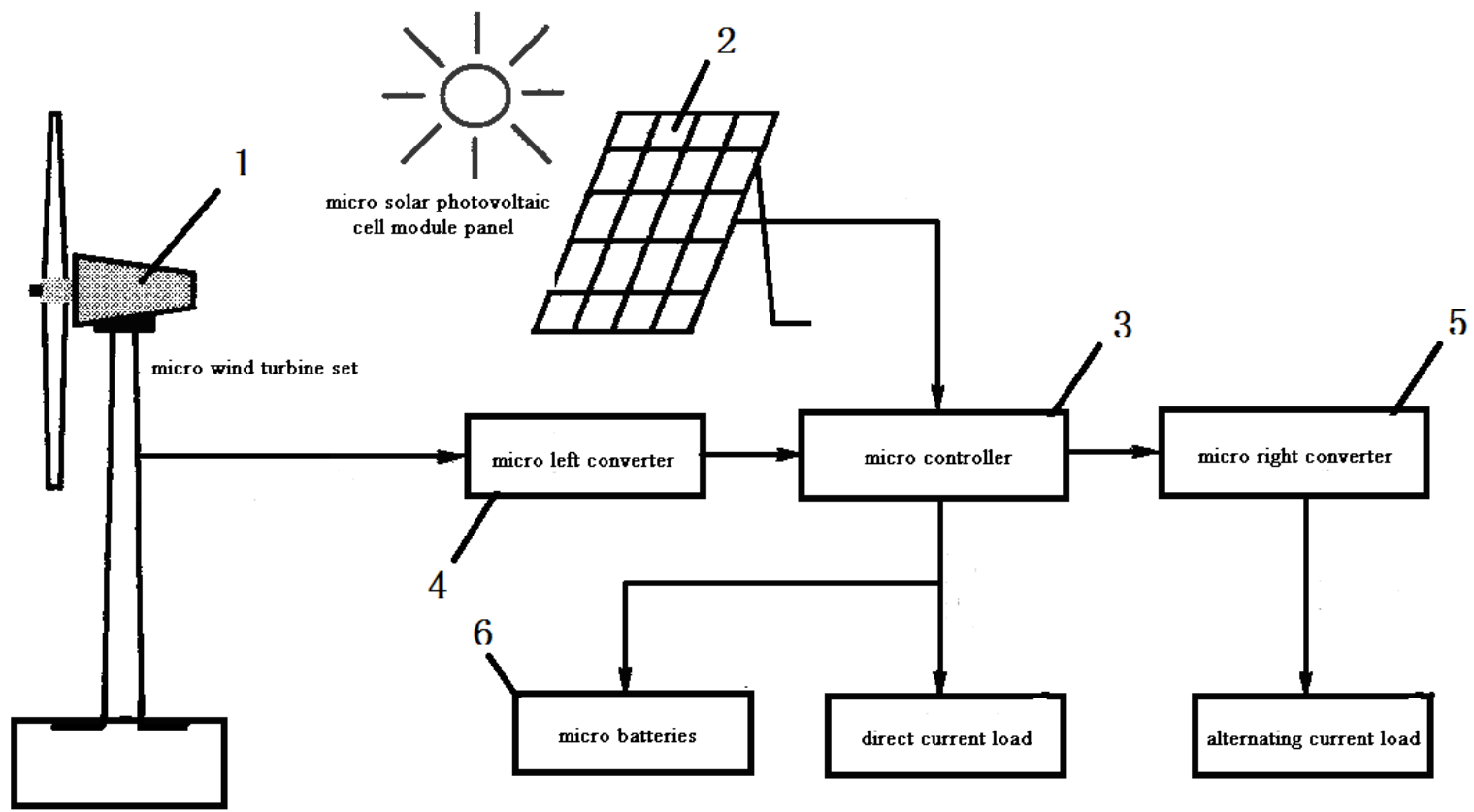

Fig. 1 basic structure for household miniature modular WPVC electric power generation facility

\section{Hardware Facility}

Micro Wind Turbine Set .In this paper, researched \& developmented "micro wind turbine set" in the household miniature modular WPVC electric power generation facilities which is a small direct drive permanent magnet synchronous wind turbine. The wind turbine directly drives the generator (between without gearbox); generator stator winding through the full power converter connected to the grid (see Figure 2), which can realize the active power and reactive power decoupling control, stable performance of the system is improved. rare earth permanent magnet generator adopts multi-stage air gap, high power density, output power big.

Because of the wind wheel of the miniature direct drive wind turbine direct drive generator, wind energy into electrical energy, wind power is decided by the size of wind speed and air density, so the quality of m objects, with the air speed of $\mathrm{V}$ kinetic energy in the flow of the wind wheel and driving wind wheel rotating mechanical energy:

$$
E=\frac{m v^{2}}{2}
$$

If the air density $\mathrm{p}$, the wind wheel swept area is A, then this case volume flow rate is Av, the air mass flow rate for P Av, the air is transferred wind energy for the wind wheel:

$$
E=\frac{(\rho v A) v^{2}}{2}=\frac{\rho A v^{3}}{2}
$$


Since all the energy in the air flow is almost kinetic energy, the upper expression is the power:

$$
P=\frac{\rho A v^{3}}{2}
$$

In fact, it is impossible for a wind turbine to convert all wind energy into mechanical energy, so the actual power of the wind turbine is:

$$
P=0.5 \rho v^{3} A C_{p}
$$

The coefficient of wind energy utilization is 0.593 in theory. That is, the maximum power obtained by the wind wheel in the flowing air is $59.3 \%$ (nearly $60 \%$ ) of the total wind energy in the range of the swept area.

Micro Solar PhotovoltaicCell Module Panel. The miniature silicon photovoltaic cell panel(See Figure 2) optimized by the " household miniature modular WPVC electric power generation facility", which photoelectric conversion efficiency can be as high as $21 \%$.

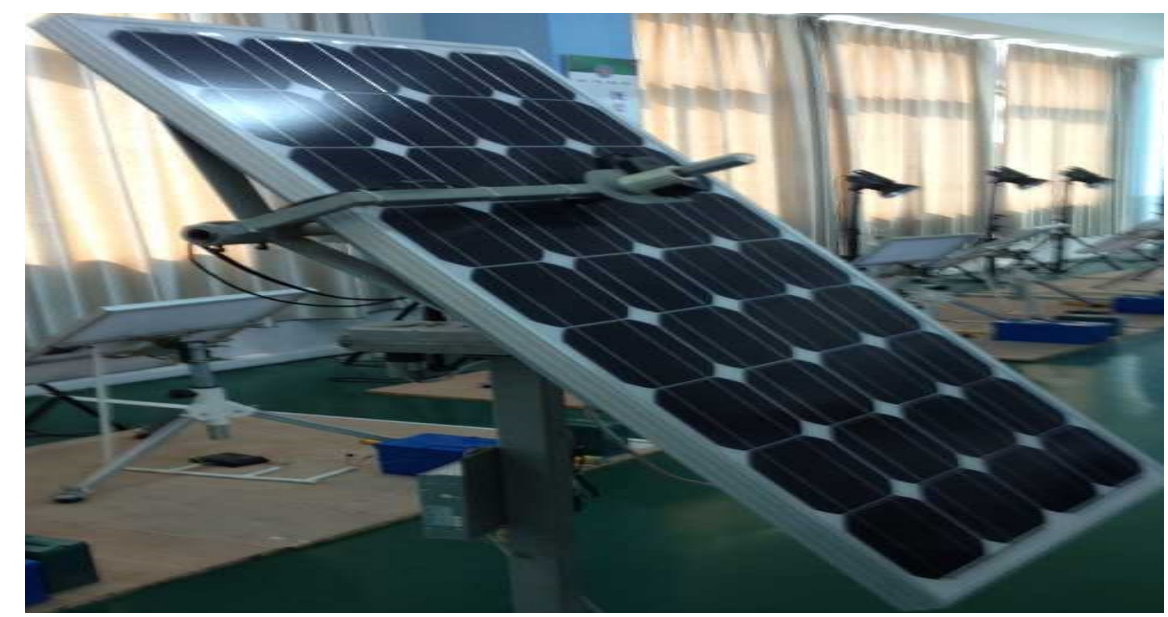

Fig.2 micro photovoltaic panel outline

Micro Controller.For wind turbines, photovoltaic module facilities, storage facilities (complementary storage battery and super capacitor energy facilities), maximum power point tracking MPPT converter facilities, (Maximum Power Point Tracking) facilities, electricity load and other facilities in the working state of the line real-time monitoring / surveillance / monitoring / monitoring (due to the changing external environment), in order to improve the efficiency of the system, the operation must rely on controller facilities to control, regulation and control. Therefore, the controller facility is the "head office" and the core facilities of the whole system, which is very important. The basic framework of controller facilities planning in this paper as shown in Figure 3, Because of the limited space, the control strategy, on the micro controller, control mode and control means with the slightly to write, also written about.The micro photovoltaic panel outline which shape outline as shown in figure 3.

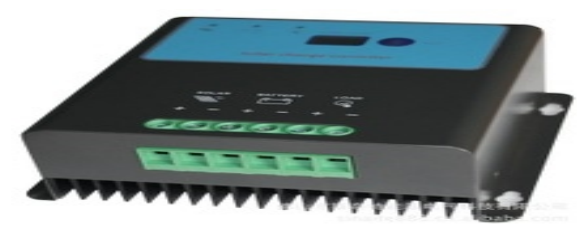

Fig.3 micro controller outline

Micro Converter. The micro converter facility mainly includes two parts: micro inverter and micro rectifier. The converter can realize the flexible connection between the WPVC electric power 
generation facilities and the interconnected power supply network (if the network connection ).As everyone knows, the inverter in the household WPVC electric power generation facility, which is normally single-phase voltage type inverter.

Micro batteries. Micro batteries in the household miniature modular WPVC electric power generation facility, which through careful planning, complementary decision using storage battery and super capacitor energy facilities, its shape outline as shown in figure 4.

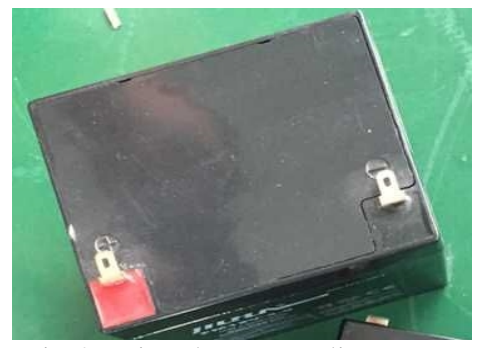

Fig.4 micro battery outline

\section{Conclusion}

The " household miniature modular WPVC electric power generation facility " researched \& developed in this paper will essentially complement the micro wind and solar power generation facilities, energy storage facilities and change.The formation of current facilities, control facilities such as the organic combination of several modular miniature power supply facilities, mainly to the electric power supply facilities family respectively, the household miniature modular WPVC electric power generation facilities, not only green, little and dainty, box, easy to move, easy installation and maintenance, and the price is high the energy (i.e., wind energy and solar energy) inexhaustible, inexhaustible, will become an important direction on development of electric energy facilities

The theoretical and experimental results show that using the current control mode, the output current of the inverter as the amount charged and real-time control of it, so it can make the output current of the inverter and grid voltage with the same frequency and phase, to achieve the purpose of power generation.

Theoretical and experimental studies show that, if the domestic miniature modular scenery complementary power generation capacity in small capacity of interconnected power network, the domestic miniature modular wind and solar power generation facilities output power fluctuations of interconnected power network voltage and frequency can be neglected.

In addition, the theoretical and experimental results show that the output current and the output voltage of solar battery and solar radiation flux density is proportional to the photovoltaic cell; neither constant voltage source nor constant current source, but a nonlinear DC power supply; and it is not possible to provide arbitrarily large power load.

\section{Reference}

[1]Zhongnian LI, Yunfeng YUE and Guoliang CHEN. Construction and Operation on the Training Base for Application Technology about New Energy Resuorce.<Advanced Materials Research>, 2895-2898, (2012)

[2]Zhongnian LI and Lei ZHOU . Research on the Fault Diagnosis System for ICM. < Advances in Manufacturing Science and Engineering>,2055-2058 , (2013)

[3]Zhongnian LI and Lei ZHOU .Research on Theory Method and Key Technology for Electric Corona Purifying Tail Gas of Automobile, <Mechatronics and Industria Informatics>,1637 -1640, (2013)

[4]ZHONGNIAN LI, TIANYING LI \& YAN QIN. Research on the Control Method with Quick Charging for Lithium-Yttrium Battery.< Proc.of ICSEEP> , 458-463, (2015) 
[5]Zhongnian LI and Lei ZHOU .Research \& Development on the MPPT Intelligent Control Device for WPVC Pwoer Generation System.< Advances in Engineering Research>, 1-5 , (2015)

[6]Zhongnian LI, etc.Research on the Development for Emerging Industries in Nantong under the National Strategy, IOP Proc. , IOP Publishing(CRC Press / Balkema), p. 012108, 1-5 , (2017) 